\title{
Szempontok a városi kormányzási elméletekhez Budapest, Bécs, Prága és Varsó közigazgatási helyzetének összehasonlítása alapján
}

\section{Expanding urban governance theories? A comparison of the administrative structures of Budapest, Vienna, Prague and Warsaw}

\author{
HILBERT BÁLINT
}

HILBERT Bálint: PhD-hallgató, Eötvös Loránd Tudományegyetem, Társadalom- és Gazdaságföldrajzi Tanszék; 1117 Budapest, Pázmány Péter sétány 1/c.; hilbert.balint@gmail.com; https://orcid.org/0000-0003-4633-4287

\section{KULCSSZAVAK: városi kormányzás; Budapest; Bécs; Prága; Varsó}

ABSZTRAKT: A városi kormányzás (urban governance) szemléletmódja az utóbbi évtizedekben népszerű kutatási témává nőtte ki magát. A kutatások középpontjában elsősorban az állami és privát szereplők együttműködése, valamint a városrégiós kormányzás kérdéskörei állnak, arról azonban lényegesen kevesebb szó esik, hogy a városok milyen tágabb jogi-közigazgatási környezetbe ágyazódnak, illetve hogy ennek milyen hatása lehet a városi kormányzás egyéb aspektusaira. Az urban governance elméleteinek nagy része a nyugati (fóként angolszász) nagyvárosokban tapasztaltakra épül, más térségek nagyvárosainak kormányzási jellemzőire ugyanakkor csekély a rálátásunk.

E kutatási deficitre reagálva a tanulmány négy közép-európai fóváros - Budapest, Bécs, Prága és Varsó - állami közigazgatási struktúrába való beépülését, belső kormányzási viszonyait (a főváros-kerület viszonyrendszert), valamint ezek 1990 óta történt változásait mutatja be. A több tekintetben hasonló fővárosok vizsgált közigazgatási jellemzői jelentős mértékben eltérnek egymástól. Budapest szinte minden vizsgálati szempont alapján élesen elkülönül a többi várostól, míg Bécs, Prága és Varsó közigazgatása több tekintetben hasonlít egymásra. A lengyel főváros Budapesthez hasonló kormányzási rendszerének közelmúltban történt radikális megváltoztatása figyelemre méltó fejlemény lehet a magyar fővárosra nézve. A négy város összehasonlítása nemcsak arra mutatott rá, hogy a városi kormányzási vizsgálatoknak számba kell venniük a városok közigazgatási környezetét, hanem egyúttal arra is, hogy Budapest kormányzása további kutatásokat igényel.

Bálint HILBERT: PhD student, Department of Social and Economic Geography, Eötvös Loránd University; Pázmány Péter sétány 1/c., H-1117 Budapest, Hungary; hilbert.balint@gmail.com; https://orcid.org/0000-0003-4633-4287

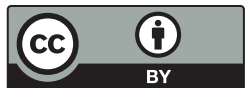


ABSTRACT: Over the past few decades, research on new aspects of urban governance has intensified significantly. The principal aim of these studies is to investigate the interconnectedness of public and private actors, as well as the cooperation between the central city and its agglomeration. However, they focus less on the cities' broader legal-administrative embeddedness into state space or on their internal governance structure (i.e. the relationship between cities and their districts). Moreover, urban governance theories are largely based on the experiences of 'Western' - especially Anglo-American - cities, while few studies focus on other regions of the world. Four Central European capital cities - Budapest, Vienna, Prague and Warsaw - are therefore examined in this paper.

The main objective of the study is to provide an overview of various factors that can influence urban governance. These are (1) the integration of capitals into the governmental structure of their respective states and the comparison of their legal status with other administrative units of the state; (2) the internal administrative structure of the cities, i.e. the relationship between the capitals and their districts; and (3) the temporal change of these two factors since 1990.

Despite the similarities between the four cities (in terms of population or historical background), the paper shows that their governance characteristics are very different. Since the public administration of states and their capitals is rooted in different historical periods, their current systems of governance are also different.

Budapest has the most distinct administrative system with its two-tier structure, which is exceptional for all factors studied. The municipalities of Vienna, Prague and Warsaw are generally similar, but they are also very different in other aspects.

By and large, the legal structure of the cities has remained unchanged since 1990, with the exception of Warsaw where it was fundamentally changed from a two-tier to a one-tier structure similar to that of Vienna and Prague over the last ten years. This may also prove remarkable for the Hungarian capital. The comparison of the four cities showed not only that urban governance studies ought to take into account the broader (external and internal) legal-administrative environment of the cities, but also the need to carry out further analyses of the governance of Budapest.

\section{Az újfajta városi kormányzás elméletéről}

Az 1970-es évektől megváltozott városi kormányzásról (angolszász nyelvterületen „urban governance”) az utóbbi évtizedekben jelentős mennyiségü tudományos munka született, elsősorban angolszász szerzők tollából, de a rendszerváltás óta több szerző munkássága révén a hazai szakirodalomban is megjelent a téma (Pálné Kovács 2008a, 2010; Somlyódyné Pfeil 2008). Az új szemléletü városi kormányzás megjelenése és kibontakozása az 1970-es évekre teheto", elsősorban a „nyugati” nagyvárosokban tapasztaltakból kiindulva. Az 1970-es évekig a városok kormányzása zárt, intézményrendszere hierarchikus és kevés szereplős volt, valamint nagy szerepe volt a költségvetésben az állami újraelosztásnak. Az erős bürokratikus kontroll és a nagyszabású állami beruházások révén a városok kormányzása üzemeltetői jellegű volt (Harvey 1989; Jelinek, Pósfai 2013). Ezt nevezik a városi önkormányzat (urban government) felfogásának, amelyet fokozatosan felváltott a városi kormányzás (urban governance) látásmódja. Ennek a váltásnak a fó mozgatórugója a beinduló nemzetközi tőkemozgás volt, amelyet a nemzetállamok egyre kevésbé tudtak 
befolyásolni, a befektetések a nemzetközi pénztőke és a helyi hatóságok közötti alkuktól váltak függővé (Harvey 1989). Vagyis a városok a tőke területi visszaágyazódásának fő színterei lettek (Brenner 2004).

Az urban governance fogalmának kiforratlanságát jelzi, hogy számos definíciója létezik:

- A városi kormányzás intézmények és szereplők rendkívül komplex, megosztott hálózata, amelyből eredendően hiányzik a konszenzus (Stone 1989).

- Az új típusú kormányzás (governance) egy önszabályozó, szervezetek közötti hálózatként értelmezhető, amelyben az érintett szervezetek között kölcsönös függőség van; a hálózatok között folyamatos interakciók tapasztalhatók; ezek az interakciók ,játékszerüek”, meghatározott szabályokra és bizalomra épülnek; a hálózat viszonylag független az államtól, noha indirekt módon a hálózatot kormányzó befolyása van (Rhodes 1997).

- A „governance” típusú kormányzásban a közhatalmi szereplők összefonódnak a gazdasági, civil szférával, illetve az egyes irányítási szintek egymással (Pálné Kovács 2008b).

- Közösségi tervezés: az állam visszavonulását fejezi ki a hagyományos hierarchikus irányítási eszközökből, illetve a társadalmi problémák közvetlen szabályozásából és ellenőrzéséből (Somlyódyné Pfeil 2008).

- Azt a folyamatot jelenti, amelynek során a demokratikusan megválasztott helyi önkormányzat és az érintettek csoportjai (gazdasági szereplök, civil szervezetek, lakosság) döntéseket hoznak a város ügyeinek intézéséről (Slack, Côté 2014).

A felsorolt definíciók közül Pálné Kovács Ilona, illetve Enid Slack és André Côté meghatározásait tartom munkám szempontjából a legmegfelelőbbnek, mivel kutatásom a közhatalmi szereplők bizonyos jellemzőinek vizsgálatára fókuszál.

Az urban governance fogalomkörével kapcsolatos kutatások több esetben foglalkoznak a kormányzás térben történő megjelenésével, amelynek keretében általában a központi város és az agglomerációja közötti közigazgatási és egyéb viszonyokat vizsgálják. A város és agglomerációja (a továbbiakban együttesen: városrégió) között fennálló igazgatási kapcsolatnak alapvetően két fajtáját határozzák meg: ${ }^{1}$ a szoros (intézményesített) és a lazább (önkéntes) kapcsolatot (Pálné Kovács 2008b). Földrajzi vonatkozásban a szoros kapcsolat alatt magát a városrégiót, lazább kapcsolat alatt pedig a városhálózatot értjük (Tóth, Sági 2009). Más megközelítés szerint a szoros kapcsolat fedi le az egy- és kétszintü kormányzási modellt, míg a laza kapcsolat a policentrikus (önkéntes alapú) kormányzási modellt (Slack, Côté 2014). Természetesen a szerzők a különböző modellek előnyeit és hátrányait is meghatározzák, azonban munkámban elsősorban az egyes típusok játszanak kiemelt szerepet:

1. Az egyszintű kormányzási modellen belül két alváltozat különböztethető meg: a fragmentált és az egységesített. A fragmentált változat esetében a városrégióban több helyi önkormányzat van jelen, akik speciális célokra hoznak létre közös szervezeteket, meghatározott szerepkörök- 
kel. Az egységesített változat esetében egy önkormányzat (a központi város) felelős a teljes városrégió ellátásáért (Hegedüs 2008).

2. A kétszintű kormányzási modell esetében a városrégiót képező több önkormányzat összefogására kialakítanak egy felsőbb kormányzó szervet, amelynek kompetenciája kiterjed az egész városrégióra. Ugyanakkor a kisebb helyi önkormányzatok sem vesztik el addigi kompetenciájukat, továbbra is biztosítják a helyi szintű szolgáltatásokat lakosaiknak.

3. A városrégió szereplői közötti leglazább kapcsolat az önkéntes alapú (policentrikus) együttműködés lehet. A helyi önkormányzatok hatáskörei teljes mértékben sértetlenek maradnak és a szereplők partnerségi kapcsolatba kerülhetnek a többi önkormányzattal. A térségi feladatokat ad hoc testületek révén látják el (Hegedüs 2008).

Összességében az urban governance elméletét leginkább a nyugati és azon belül is kimondottan az angolszász városokban bekövetkezett változásokra fogalmazták meg. Az „új városi kormányzási” modell megvalósításának feltételei azonban a világ nagyvárosaiban különbözőféleképpen és különböző időben valósulhatnak meg. A városok különböző államok közigazgatási rendszerében foglalnak helyet, amelyek egyúttal jelentősen eltérő jogszabályi környezetet is jelenthetnek. Az urban governance elméleteinek nagy részében is megjelenik a közhatalmi szereplők befolyása a városi kormányzásra, azonban a témában íródott szakirodalmak elsősorban az állami és a magánszféra szereplőinek együttműködését emelik ki, valamint az állam „visszavonulását” hangsúlyozzák. A városi kormányzás földrajzi kutatásai a város belső kormányzási struktúrája helyett sokkal nagyobb hangsúlyt fektetnek a város és környező közigazgatási egységek kapcsolatára, vagyis a városrégió menedzselésének kérdésére - bár Pálné Kovács (2010) kiemeli a „városfalakon” belüli és kívüli szereplőkkel való együttműködés fontosságát. A városrégiós tipizálást a főváros-kerület relációban is lehet és érdemes is volna értelmezni, amelyet tanulmányomban a vizsgált városokra megvalósítok. A jogszabályi feltételeket továbbra is az állami szereplők alakítják ki, a város legfőbb döntéshozó és végrehajtó hatalma a városi önkormányzat, mind a privát szereplőkkel, mind más önkormányzatokkal való együttműködésben. Az eddigi kutatásokból nem sokat tudhatunk meg a városi önkormányzat rendszeréréről sem, nevezetesen a kerületi és a fővárosi szint jogi viszonyáról, hiszen nem mindegy, hogy a város kormányzása, illetve az abba való beleszólás hány szereplő között oszlik meg.

Az „új városi kormányzási” irodalmakban felfedezhető hiányosságokból, vagyis a városi önkormányzat jellemzőinek alulreprezentáltságából kiindulva a tanulmány elsődleges célja áttekintést nyújtani négy közép-európai fóváros (Budapest, Bécs, Prága, Varsó) állami közigazgatásban elfoglalt pozíciójáról és belső kormányzási viszonyairól, illetve azok időbeli változásairól (elsősorban az utóbbi évtizedekben). A tanulmány fó kutatási célkitűzése így nem az urban governance elméletek gyakorlatban tapasztalható jellemzőinek vagy a négy város kormányzási hatékonyságának a felmérése, hanem - a fővárosok közigazga- 
tási vagy kormányzási eltéréseire történő rávilágítással - az urban governance elméletek finomítása és újraértelmezése.

A kutatás fö szempontjai és vizsgálat részletei a következők:

1. szempont: Az állami közigazgatásban betöltött pozíció: a fóváros közigazgatását meghatározó jogszabály(ok), valamint a főváros beágyazódása az állami közigazgatási rendszerbe.

2. szempont: A fövárosi és kerületi szint viszonyrendszere: a fővárosi kerületek jogi pozíciója a város döntéshozatali rendszerében, a kerületeknek biztosított hatáskörök, illetve a városrégiós tipizálás alkalmazása a viszonyrendszer jellegének megállapítására.

3. szempont: A városi közigazgatás időbeli változásai: az előző két szempont 1990 óta történt változásai.

\section{A vizsgált városok és a kutatás módszerei}

Budapest közigazgatási helyzetéről bőséges szakirodalom áll rendelkezésre, amelyek általában a városi közigazgatás rendszerszintű problémáira hívják fel a figyelmet (Dövényi, Knabe 2007; Pálné Kovács 2008a; Perger 2004). Kevés olyan publikációt találhatunk, amelyben fóvárosunkat nemzetközi perspektívából, más nagyvárosokkal összevetve vizsgálják, ami két okból is nagy hiányosságnak számít. Egyrészt a nemzetközi összevetés más megvilágításba helyezheti Budapest kormányzási rendszerét, másrészt a külföldi tapasztalatok hozzájárulhatnának a magyar főváros kormányzásának jövőbeli fejlesztéséhez.

Egy nemzetközi összehasonlítás keretében a legkézenfekvőbbnek tűnik a Budapesthez földrajzilag közel lévő, a fóvárosra több szempontból (történelmi hátterüket, területi kiterjedésüket, népességszámukat tekintve) hasonlító nagyvárosokat elemezni. Ezek figyelembevételével tanulmányomban Budapestet Béccsel, Prágával és Varsóval vetem össze. A történelem során a négy város, ha nem is mindig egyszerre, de sokszor hatott egymásra. A Habsburg Birodalom és az Osztrák-Magyar Monarchia Bécset, Budapestet és Prágát, a szocialista blokk pedig a magyar, a cseh és a lengyel fóvárost hozták egy politikai egység keretei közé. Ma az Európai Unió politikai keretein belül fejlődik mind a négy város. Az említett települések vizsgálata melletti további érv, hogy népességszámuk szinte azonos (kivéve Prágát), valamint némelyikük között igen szoros partnerségi kapcsolatok állnak fenn (Hilbert 2017). A kutatási téma szempontjából Közép-Európa érdekes helyszín, hiszen a politikai, gazdasági és társadalmi átmenetben lévő posztszocialista városok mellett az egykori nyugati blokk városai is megtalálhatók. Ráadásul a nyugati urban governance kutatások szemszögéből Közép-Európa még „,ismeretlen” terepnek számít.

A kutatás empirikus része nagyobbrészt a négy fővárosra vonatkozó állami jogszabályok, fejlesztési dokumentumok és kisebbrészt szakirodalmak feldolgo- 
zására és értelmezésére épül. Prága és Varsó közigazgatásának vizsgálata során csupán az angol nyelvű szakirodalmakra és az angol nyelvre lefordított törvényszövegekre támaszkodtam.

\section{Négy közép-európai főváros közigazgatási rendszerének ismertetése}

\section{Budapest közigazgatása}

A magyar főváros állami közigazgatási rendszerbe való beilleszkedése és a város kormányzási rendszerét meghatározó jogszabályok 1990 óta nem igazán módosultak. Jelenleg a fóváros közigazgatási felépítését a 2011. évi Alaptörvény, valamint a Magyarország helyi önkormányzatairól szóló 2011. évi CLXXXIX. törvény szabályozza, amelyek értelmében Budapest közigazgatása kétszintű: fövárosi és fővárosi kerületi önkormányzatok szintjéből áll, vagyis a fóváros egyszerre rendelkezik területi és települési önkormányzati jogokkal, Budapest a magyar közigazgatási rendszeren belül két eltérő szint hatásköreit egyesíti. Vélhetően emiatt nincsen a magyar fővárosra vonatkozó külön jogszabály, habár ennek megalkotására a helyi önkormányzatokról szóló 1990. évi LXV. törvény 68 . paragrafusának 2 . pontja ígéretet tett.

A második vizsgálati szempontból - a föváros és a kerületek viszonyrendszere - Budapest egyedülálló a vizsgált fővárosok közül. A két közigazgatási szint alapjogaikat tekintve egyenlő, de feladat- és hatásköreikben különbözik egymástól. A kerületek saját maguk hozzák meg egyes ügyekről a döntéseiket, a fővárossal csak egyeztetési kötelezettségük van (Perger 2004). A fóvárosnak viszont konzultációs fórumot kell létrehoznia a kerületekkel való könnyebb együttműködés céljából. Az önkormányzatok olyan fontos települési jogkörökkel rendelkeznek, mint a saját költségvetés, illetve az építési engedélyek kiadása. A fóváros és a kerületek is rendelkeznek tulajdonnal Budapest területén, amelyekhez jogok, kötelezettségek és feladatok társulnak (1. ábra). A kétszintu” önkormányzati rendszer igencsak megnehezíti a főváros igazgatását, ugyanis a feladatok elosztása a föváros és a kerületek között alapvető probléma (Perger 2004). További nehézségeket okoz a főváros túlzott decentralizáltsága a közös fejlesztési célok kitűzésében: minden kerület külön készít kerületfejlesztési koncepciót, amelynek megalkotási folyamatában nem kell kötelezően konzultálni más kerületek vezetőivel.

Budapest közigazgatásában 1990 óta nem tapasztalható nagyobb horderejü módosítás. Először az 1994. évi LXIII. törvény (1994. évi LXIII. törvény a helyi önkormányzatokról szóló 1990. évi LXV. törvény módosításáról) értelmében a Fővárosi Önkormányzat olyan jogokat kapott, amelyekkel bizonyos mértékben 
1. ábra: Budapest közigazgatási struktúrájának sematikus ábrája The structure of Budapest's government

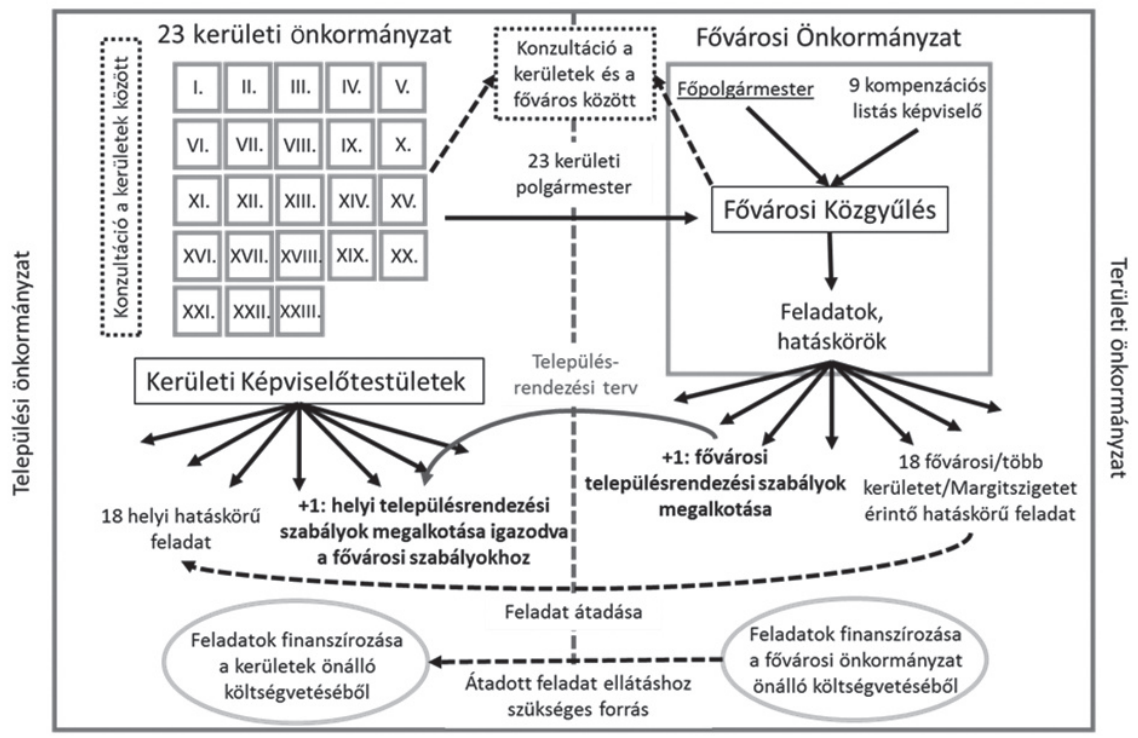

korlátozni tudja a kerületek önállóságát (a terület- és településrendezési szabályok megalkotásánál), illetve a főváros területén képződött adóból származó bevételek megosztásával („megosztott források”) szorosabbá vált a kerületek és a főváros viszonya. 2014-től a kerületi polgármesterek bekerültek a Fővárosi Közgyűlésbe (2011. évi CLXXXIX. törvény Magyarország helyi önkormányzatairól), ahol együtt kell megszavazniuk a Budapest egészét érintő ügyeket a fópolgármesterrel, illetve a 9, kompenzációs listáról bekerült képviselővel.

Habár valamelyest központosítottabbá vált a város vezetése, az erős, települési jogú kerületeket figyelembe véve még mindig igen decentralizáltnak számít Budapest közigazgatása. Egy erős, kerületeket összefogó fővárosi szint hiányát jelzi az a tény, hogy a kerületek bizonyos feladatok elvégzésére a Fővárosi Önkormányzat kihagyásával is társulhatnak. A Fővárosi Önkormányzat Szervezeti és Működési Szabályzatának - 53/2014. (XII. 12.) Főv. Kgy. rendelet a Fővárosi Önkormányzat Szervezeti és Működési Szabályzatáról - IX. fejezete (a Fővárosi Önkormányzat és a kerületi önkormányzatok kapcsolatrendszeréről) egyértelmüsíti a jelenlegi csekély interakciót Budapest közigazgatási szintjei között, amely szerint a két önkormányzati entitás közötti együttmüködés csupán a főváros által átadott feladat- és hatáskörök évenkénti egyszeri egyeztetésére, valamint a már említett konzultációs fórumon való egyeztetésre korlátozódik. Kérdéseket vet fel továbbá a kerületi polgármesterek Fővárosi Közgyülésben való jelenléte, ugyanis a polgármesterek szavazata a javaslatok elfogadásánál különböző súllyal esik latba, az általuk vezetett városrész választópolgárai létszámának figyelembevételével. A legnagyobb (XI. kerület - 111 ezer választópolgár) és a legkisebb 
(XXIII. kerület - 19 ezer választópolgár) kerület polgármesteri szavazatának súlya között többszörös különbség van (Sulyok 2015).

Érzékelhető Budapest állami közigazgatásba való beépüléséből, de fóként a város belső adminisztratív felépítéséből, hogy a magyar fővárosban az urban governance definícióiban hangsúlyos szempontok (az állami és a magánszféra közötti, valamint a városrégiós együttműködések) vizsgálata igen körülményes. Budapest közhatalmi szereplöinek viszonya önmagában is elég bonyolult, ráadásul a magyar fóváros nem élvez különleges jogköröket Magyarországon belül. Ezek a tényezők a városi kormányzásra hatással levő, különböző szférákban jelen levő szereplők érdekeinek összehangolását nehezítheti meg.

\section{Bécs közigazgatása}

Az első elemzési szempont szerint Bécs Ausztrián belüli közigazgatása különleges, mivel a város egyszerre képezi az ország egyik szövetségi tartományát és egyben önkormányzatát. Bécs mint szövetségi tartomány törvényhozó és végrehajtó testületeket állíthat fel, valamint joga van tizenegy képviselőt küldeni a szövetségi gyűlésbe. Habár az osztrák főváros külön tartományi és önkormányzati szervekkel is rendelkezik, az azokat irányító szereplők azonosak. Minden tartományi szerv hatáskörét az önkormányzati megfelelője gyakorolja, így a polgármester egyben a tartományi kormányzó, a városi szenátus a bécsi tartományi kormány, illetve a városi tanács tölti be a bécsi tartományi parlament szerepét (Stadt Wien 2011).

Bécs mint önkormányzat alapszabályait az 1968-ban megalkotott és azóta többször módosított Bécs városi alkotmány (Wiener Stadtverfassung) szolgáltatja (Landesgesetzblatt Wien é. n.). A városi alkotmány szerint Bécs fö döntéshozó szerve a városi tanács, amely az egész várost önálló költségvetésével egyedül irányítja. A városi tanács rendelkezik a város összes vagyonával és feladataival, tehát Bécs erősen centralizált kormányzású főváros. A Bécs városi alkotmány ugyanakkor előírja egyéb, a szövetségi alkotmányban nem elöírt szervek létrehozását, ilyenek a hivatalt vezető városi tanácsosok, a városi tanács bizottságai és a kerületi tanácsok. A városi alkotmány Bécs városában 23 kerületet határoz meg, amelyek szervei a kerületi tanács és annak igazgatója, illetve a kerületi bizottságok.

A főváros-kerület viszonyrendszer az osztrák fővárosban jóval egyszerübb a magyar fóvároshoz képest, ugyanis a kerületek szervei a főváros szerveibe integráltak, azoknak alárendeltek. Az egyes kerületek tehát nem jogi személyiségek, hanem Bécs város részei (2. ábra). Ahogyan Budapesten a városi kormányzás központosítására, úgy Bécsben annak decentralizálására van folyamatos törekvés a városvezetés felől. A kerületek mozgásterét, beleszólását a város irányításába az idők folyamán egyre szélesítették. A kerületi mozgástér kibővítése négy lépcsőben zajlott a 20 . század második felében: 
1. A kerületek informálása a város ügyeiről.

2. A kerületek meghallgatása a város ügyeit tekintve.

3. A kerületek aktív részvétele a város ügyeiben mint javaslattevő szereplők.

4. A kerületek és a főváros által delegált és finanszírozott feladatainak ellátása (amellyel kerületi költségvetés és döntési jogkör is együtt járt).

Az utolsó, negyedik lépcsőfok megvalósítására 1988. január elsején, a városi alkotmány kibővítésével került sor (Landesgesetzblatt Wien é. $n$.). A kerületek az alkotmányban megállapított feladatokon kívül újabbakat kaphatnak a városi tanácstól vagy a polgármestertől. A kerületek összes feladata és összes bevétele a városi tanácstól származik, költségvetésük Bécs város költségvetésének része. A feladatok ellátásához szükséges pénzt a kerületek a fóvárostól kapják területük, népességük, fejlesztéseik és a mindenkori speciális feladatok szerint. A kerületek részt vesznek a városi döntéshozatalban, egyes esetekben részvételi, más esetekben konzultációs joggal rendelkeznek. A kerületek javaslatait a legmagasabb rangú személy, a kerületi elöljáró (Bezirksvorsteher) közvetíti a bécsi városi tanácsnak. Bécs városnak továbbá kötelezően kell tárgyalnia a kerületek vezetőivel, mielőtt egy fontosabb rendeletet megszavazna a városi tanács. Kötelező a városi tanácsnak tájékoztatnia az egyes kerületek igazgatóit minden készülődő, a város több kerületét érintő tervezet előtt (Amtsblatt Wien 2007). Tehát az osztrák fóváros kerületei csak közvetett módon tudnak beleszólni a város irányításába, a főváros által hozott döntések végrehajtását sem hátráltatni, sem megakadályozni nem tudják.

2. ábra: Bécs közigazgatási struktúrájának sematikus ábrája The structure of Vienna's government

Tartományi szerepkör

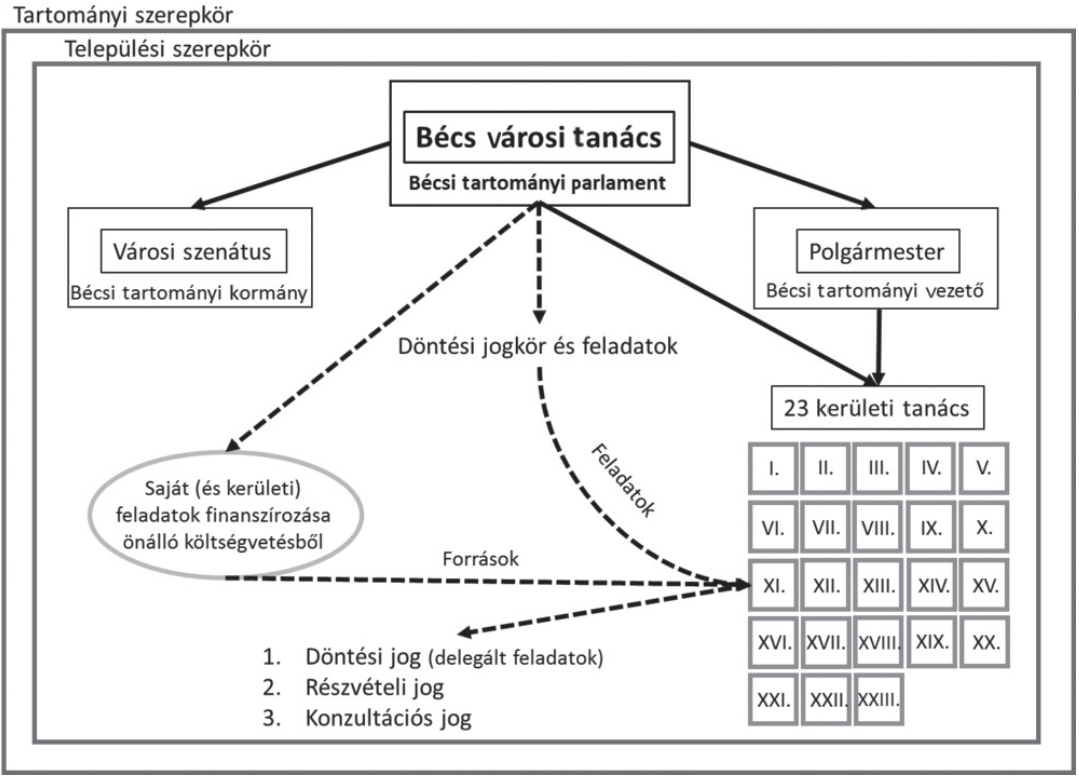


Bécs közigazgatása történelmileg igen stabil. A város állami igazgatási rendszerbe való beépülése 1922 óta, belső adminisztratív felépítése 1968 óta állandónak tekinthető. Az osztrák főváros kormányzásának centralizáltsága, szövetségi tartományi létéből eredő szélesebb jogi eszközrendszere, illetve közigazgatásának időbeli stabilitása minden bizonnyal teljesen más körülményeket teremt az urban governance gyakorlati megvalósulására, mint azt Budapest esetében feltételezhettük.

\section{Prága közigazgatása}

Az első elemzési szempont szerint Prága közigazgatási pozíciója Csehországban - Bécshez és Budapesthez hasonlóan - többrétűnek számít, ugyanis egyszerre helyi önkormányzat és régió. Ennek ellenére Prágára nem érvényesek sem az önkormányzatokra, sem a régiókra vonatkozó jogszabályok, hanem egy 1990-ben speciálisan a cseh fővárosra született törvény (Předpis č. 418/1990.) tartalmazza közigazgatási kompetenciáit. Ennek értelmében Prága sajátos jogi eszközrendszerével Csehország egyik közigazgatási szintjét alkotja.

A főváros és a kerületek viszonyának rendezéséről a rendszerváltást követően nem alakult ki konszenzus az állami és a városi szereplők között, két csoport érdekei ütköztek egymással: a fóvárosi centralizációt, illetve a decentralizációt követelőké. A szocializmus évtizedei alatt Prága városi irányítása igencsak szétaprózódott, három szinten (fővárosi, kerületi és települési) kormányozták a várost. Az egykori kerületek vezetői egyértelműen Prága decentralizált kormányzási rendszere mellett foglaltak állást. A centralizációt követelő szereplők (a fövárosi szint, illetve Csehország vezetői) viszont a szocializmus előtti idők (az első Csehszlovák Köztársaság) tapasztalatára visszanyúlva egy önkormányzatot kívántak kialakítani Prágában. Végül a centralizáció híveinek érdeke kerekedett felül és az 1990-es Prágára vonatkozó törvény szerint a cseh főváros egy önkormányzatot alkot, amelynek szerves része 56, önkormányzati státusz nélküli kerület (1992-ben 57-re bővült a kerületek száma) (Horak 2007).

Érdekes módon a szocializmus alatt kialakított közigazgatási rendszert nem törölték el véglegesen, csupán a szintek jogkörét csonkították meg, illetve alakították át. 2002-ben egy újabb kerületi szinttel bonyolították a főváros közigazgatását, így ma a következő városi kormányzási szintek különböztethetők meg Prága területén (3. ábra):

1. Prága Fővárosi Önkormányzat: A fővárosi közigazgatási szint az egyetlen Prágában, amely önkormányzati jogkörrel rendelkezik (speciális fővárosi hatáskör). A fővárosi önkormányzatnak saját költségvetése és döntési jogköre van. A föváros legfontosabb döntéshozó szerve, Prága városi tanácsa pedig az egyedüli a cseh főváros területén, amelynek joga van helyi adókat kivetni, ${ }^{2}$ továbbá javaslatot tehet a fóváros kerülethatárainak megváltoztatására is. 
3. ábra: Prága közigazgatási szerkezetének sematikus ábrája The structure of Prague's government

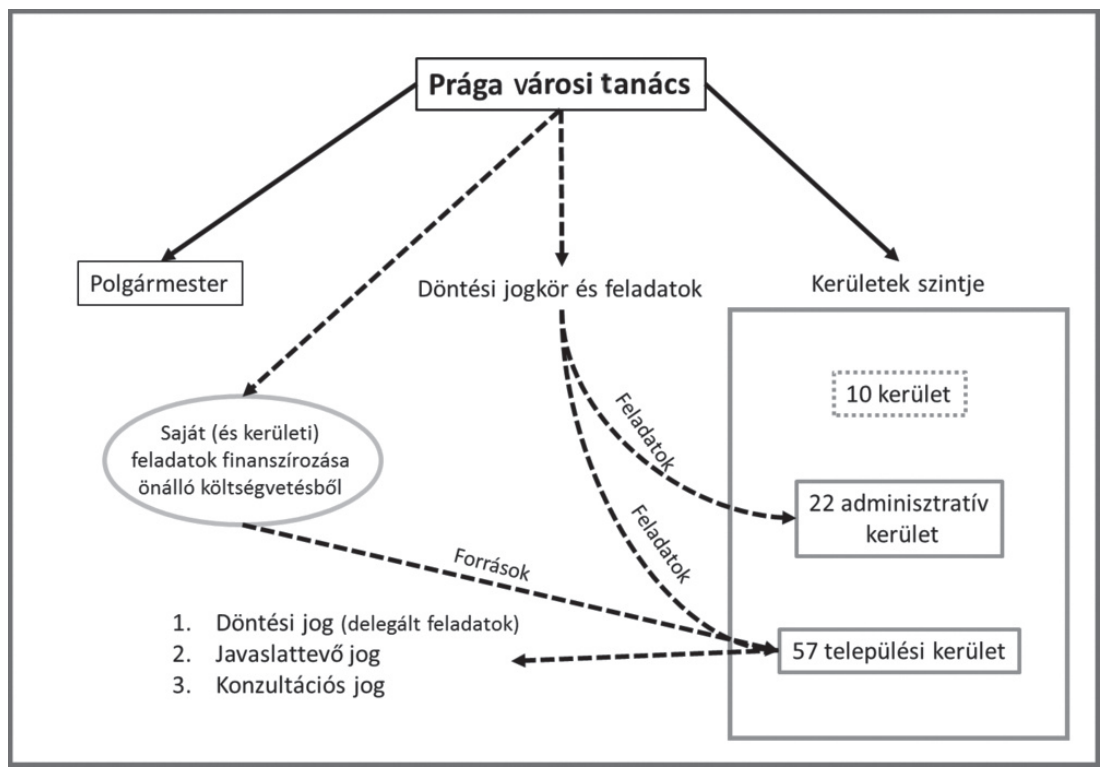

2. 10 kerület: Az 1960-ban létrehozott 10 kerületet (amelyek egykor önkormányzati joggal rendelkeztek, de 1990 óta csak formálisan léteznek) ma csak a bíróságok, a postahivatalok és egyéb közigazgatási szervek veszik figyelembe.

3. 22 adminisztratív kerület: 2002 óta ezzel a szinttel bővült a főváros irányítási struktúrája. Az 56 (majd 57) egykor önkormányzati jogokkal rendelkező kerületet 22 adminisztratív kerületbe csoportosították, amelyek jelentősebb hatáskört nem kaptak. Az adminisztrációs kerületek nevükből eredendően csak bizonyos lakossági ügyeket intéznek, tehát a többi kerületi szinthez hasonlóan semmiféle önkormányzatisággal nem rendelkeznek.

4. 57 települési kerület: Az 56 (majd 57) kisebb települési kerület szintén nem rendelkezik önkormányzati joggal, azonban számos, kerületeket érintő ügyben döntési, javaslattevő és konzultációs joguk van, illetve a fóváros által delegált feladatokat ellátják. A feladatokhoz a főváros pénzügyi forrásokat is biztosít, így a kerületek (valamelyest önállóan) költségvetéssel is rendelkeznek. Az 57 kerületnek választott képviselötestülete és polgármestere is van. A kerület legfőbb szerve a kerületi tanács, amely véleményezheti Prága városrendezési és városfejlesztési tervét, költségvetését, valamint dönt helyi népszavazás tartásáról és más kerületekkel, illetve szervezetekkel való együttműködésről. A kerületek folyamatosan konzultálhatnak a fővárossal és más kerületekkel bi- 
zonyos ügyekben. A fóvárosi önkormányzat további feladatokat adhat át a kerületeknek, de ahhoz pénzügyi forrásokat is biztosítania kell a fơvárosnak (Horak 2007).

Prága közigazgatása időben viszonylag stabil, hiszen az állami közigazgatásba épülése 1990 óta változatlan, és a fővárosi és kerületi szint jogi viszonyrendszere sem változott érdemben. A cseh főváros közigazgatási jellemzői (különálló közigazgatási szint az államon belül, összetett kerületi felépítés) az urban governance elméleteiben említett fókuszpontokat tekintve az osztrák és magyar fővárosoktól eltérő helyzetet teremthet.

\section{Varsó közigazgatása}

Varsó közigazgatási helyzete Lengyelországon belül a másik három fövároshoz hasonlóan kivételes: városi státusszal rendelkezik, de megyei jogokkal bír (megyei jogú város). Varsó közigazgatási rendszerét a 2008-ban megalkotott Varsó városi törvény (Nr. XXII/743/2008.) szabályozza, amely jelzi a lengyel föváros különleges helyzetét a lengyel önkormányzati rendszerben.

Mind az államon belüli közigazgatási helyzetét, mind a fóvárosi és kerületi szint viszonyrendszerét tekintve a lengyel fóváros ment át a legtöbb változáson az 1990 óta eltelt évtizedek alatt, illetve az egyedüli város volt, amelynek területi kiterjedése is változott. 1990-ben Varsó hét, önkormányzati joggal rendelkező település (kerület) laza szövetségeként alakult újjá, ahol a kerületek közötti összeköttetést egy gyenge fővárosi szint biztosította, amely jogilag nem rendelte maga alá a kerületeket (Moreno 2012). A fóvárosi szint még tulajdonnal sem rendelkezhetett, csupán felügyelő és koordinációs szerepet töltött be. A kerületi polgármesterek jóval szélesebb jogokkal bírtak, mint a varsói föpolgármester. 1994 és 2005 között Varsó területi kiterjedése folyamatosan nőtt (485-ről $517 \mathrm{~km}^{2}$-re) újabb és újabb agglomerációs települések beolvasztásával (Eckardt, Elander 2009). A 1990-es években úgy gondolták Lengyelország vezető politikusai, hogy Varsó decentralizáltsága előnyt jelenthet a fóvárosnak azzal, hogy az erős kerületek saját fejlődésük és a közös, fővárosi fejlődés érdekében erőfeszítéseket tesznek (Council of Europe 2002). Azonban a tapasztalat azt mutatta, hogy a kerületek egymással szembefordulva rivalizáltak a befektetőkért, ami hosszú távon a fontos fővárosi szintü beruházások késését, illetve hiányát idézte elő. Varsó mint főváros a kerületek rivalizálása révén nem rendelkezett egységes fejlesztési fókusszal, a folyamatos érdekellentétek miatt többször is leállt a fóvárosi rendeletalkotás (Horak 2007).

Vélhetően az 1990-es évek tapasztalataiból kiindulva 2002-ben radikális változásokat hajtottak végre Varsó közigazgatási rendszerében, a lengyel főváros egy önkormányzatú településsé vált. Az egykori kerületek (települések) elvesztették önkormányzati jogukat és a főváros alá rendelődtek teljes mértékben, vagyis önálló jogi szereplőkből egy város „tartozékaivá” váltak. Varsó 
városi tanácsa lett a főváros vagyonának egyedüli tulajdonosa, így az egyetlen költségvetés kezelője és a feladatok ellátásáért felelős szerve is. A megyei önkormányzat külön intézményrendszere megszűnt, hatáskörét a városi tanács vette át. Tehát a lengyel főváros három közigazgatási szintből tevődik össze (megye, főváros, kerületek), viszont a város kormányzásának joga teljes mértékben a városi tanács kezében összpontosul (4. ábra). 2002 után elkészülhetett a lengyel főváros első koherens fejlesztési stratégiája, így egy évtizedes késéssel megindulhatott Varsó mint egységes város fejlesztése. Varsó fóvárosi szintje, amely korábban csak felügyelő és koordinációs feladatokat látott el, az új jogszabályi rendelkezés értelmében igen széles eszközrendszert kapott, így például joga van új kerületek létrehozására, kerületek egybeolvasztására, de akár megszüntetésére is. Varsó Bécshez és Budapesthez hasonlóan kettős szerepkörrel rendelkezik, városi és megyei feladatokat is ellát.

A föváros-kerület viszonyrendszerben a lengyel főváros az osztrák és a cseh fóvárosokhoz hasonlítható. Varsó 18 kerülete önkormányzati joggal nem rendelkezik, minden szempontból a főváros szerves részét képezik, a városi tanács nevében kezelik a területükön lévő tulajdont. A kerületi tanácsok fö teendője a Varsó városi tanácsa által delegált feladatok ellátása. A városi tanács és a fópolgármester további feladatokat vagy tulajdont tud átadni a kerületeknek, amelyek megvalósításához forrásokat is allokálnia kell. A kerületi tanácsok a delegált feladatokhoz döntési jogkört is kapnak, a főváros költségvetésére javaslatot kell tenniük, illetve konzultációs joguk van bizonyos fövárosi ügyekben.

\section{4. ábra: Varsó közigazgatási szerkezetének sematikus ábrája}

The structure of Warsaw's government

Városi státusz - megyei szerepkör

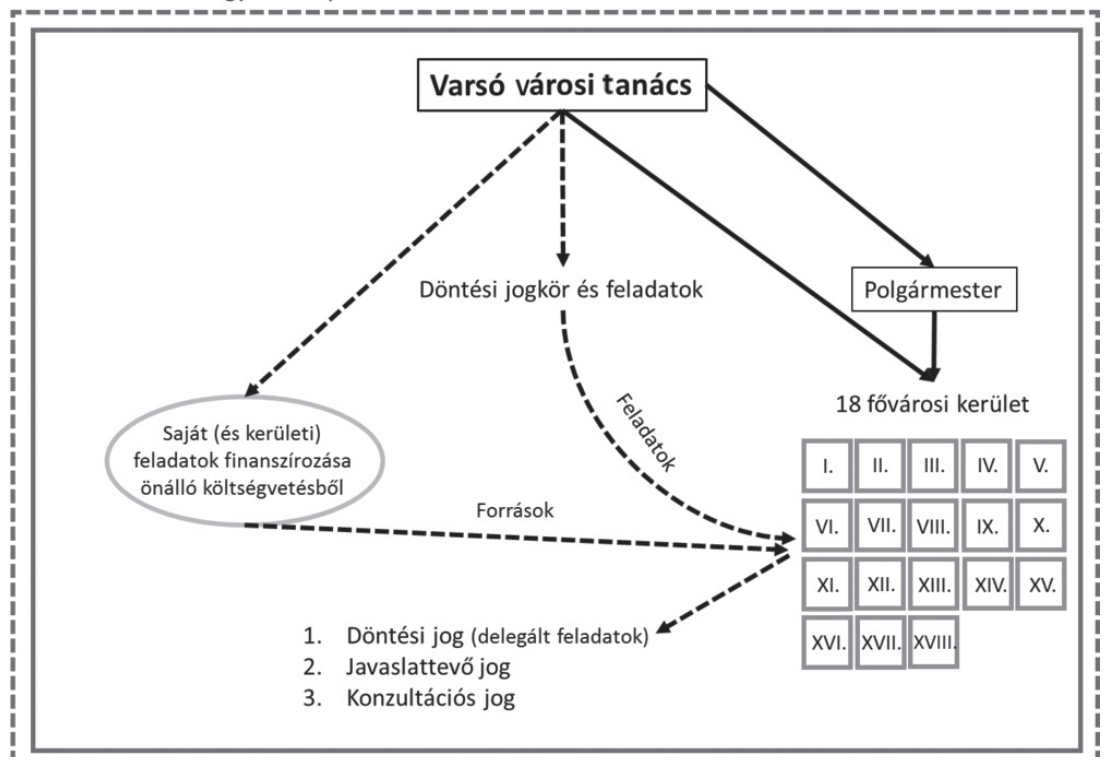


Vagyis a varsói kerületek mozgástere igen szük, ami minden bizonnyal jelentős váltásnak tudható be a 2002 előtti kerületi jogszabályi körülményekhez képest.

Varsó közigazgatása 1990 óta jelentős változásokon esett át, a lengyel föváros külön jogi eszközökkel rendelkező, centralizált irányítású településsé alakult az utóbbi évtizedekben. A város jogi-közigazgatási helyzetének, valamint területi kiterjedésének drasztikus változásai kétségkívül jelentős hatással lehettek a város urban governance elméletek által értelmezett kormányzására is.

\section{Összegzés}

A négy fóváros állami közigazgatási rendszerbe való beágyazottságában több különbség mutatkozik, mint hasonlóság. Minden vizsgált városban tapasztalható volt a kettős státusz jelenléte (helyi önkormányzati és megyei-tartományi-régiós státusz), de az ezekhez kapcsolódó jogi eszközrendszer merőben eltért egymástól. Bécsben és Budapesten a kettős státuszhoz kettős eszközrendszer kapcsolódik, azonban ez az osztrák fóvárosban egy, míg Budapesten 1+23 szereplőt érint. Prágában és Varsóban a kettős státusz ellenére államukon belül speciális jogszabály érvényes rájuk és Bécshez hasonlóan ezek egy önkormányzat hatáskörébe tartoznak. Az államon belüli kivételes helyzethez kötődve Bécsnek, Prágának és Varsónak egyedülálló jogi eszközrendszerük és szélesebb mozgásterük van, míg Budapest gyakorlatilag két magyar közigazgatási szint hatáskörével rendelkezik. Ezt a különbséget a jogszabályok is megerősítik, ugyanis csak Budapest nem rendelkezik külön a városra alkotott törvénnyel. Nem feledkezhetünk meg arról sem, hogy Ausztria (szövetségi állami) államformájából kiindulva Bécs tartomány törvényhozói hatalommal rendelkezik, a többi város esetében nem beszélhetünk hasonló kompetenciáról.

A városok belső adminisztratív felépitése és a hatáskörök eloszlása is sokban különbözik egymástól. A fő választóvonal Budapest és a többi főváros között húzódik, ugyanis a magyar fővárosban a kerületi és a fóvárosi szint jogilag egyenlő, míg Bécsben, Prágában és Varsóban a kerületi szint alá van rendelve a fővárosinak (vagyis csak a budapesti kerületek rendelkeznek önkormányzati joggal és az ezzel együtt járó költségvetési és építési jogokkal). A városrégiós tipizálás szerint Bécs, Prága és Varsó főváros-kerület viszonyrendszerét tekintve az egységesített egyszintű modellbe tartozik. Budapest belső közigazgatási struktúrája nem sorolható be egyértelmüen egyik városrégiós kategóriába sem, véleményem szerint a kétszintű és a policentrikus modell közötti változatként értelmezhető. Budapesten két szinten 24 egyenjogú szereplo, míg a többi városban gyakorlatilag egy szereplő hoz döntéseket a kormányzásban. A kerületek érdekeinek képviselete is eltérő a vizsgált városokban. Budapesten a kerületi polgármesterek a Fővárosi Közgyülésben szavazati joggal rendelkeznek, míg a többi város kerületei csak a főváros által delegált feladatokban dönthetnek, a 
fóváros által biztosított forrásokkal a kezükben. A városrégiós tipizálás szerint Bécs, Prága és Varsó főváros-kerület viszonyrendszerét tekintve az egységesített egyszintü modellbe tartozik.

A közigazgatási szerkezet 1990 óta történt módosulásaiban a lengyel föváros bizonyult a kivételnek. Varsóban az utóbbi évtizedekben nemcsak a közigazgatási rendszer, de a területi kiterjedés is többször megváltozott. A lengyel fóváros kétszintű közigazgatási rendszerét módosították egyszintűre, amelynek során az addig önkormányzati joggal nem rendelkező fővárosi szint „helyet cserélt” az ugyanezen jogokkal addig rendelkező kerületekkel. Ez a váltás annak fényében is érdekes, hogy a lengyel fővárosban egy budapestihez hasonló rendszert módosítottak egy Bécshez és Prágához hasonlító rendszerre. Budapest és Prága közigazgatási rendszere 1990 óta viszonylag állandó, csak kisebb átszervezéseket hajtottak végre. A legstabilabb közigazgatási szerkezetű város egyértelműen Bécs, amelynek városi jogszabályát 50 éve alkották meg és a legutolsó jelentős módosítást 1988-ban hajtották végre.

A fővárosok kormányzásának három szempont szerinti áttekintése után érzékelhető, hogy a bevezetőben megfogalmazott új szempontú városi kormányzás teljesen eltérő közigazgatási környezetben nem működhet ugyanúgy. A nemzetközi urban governance kutatások szempontjából alulreprezentált közép-európai térségben a négy fóváros közigazgatási rendszerének összehasonlítása figyelemreméltó eredményeket hozott. Az kevésbé meglepő, hogy az egykori Vasfüggöny nyugati oldalán levő Bécs közigazgatása a legstabilabb, az azonban már váratlanabb tapasztalatnak bizonyult, hogy a posztszocialista fóvárosok között milyen nagy eltérések mutatkoztak (főként Budapest éles elkülönülése a többi várostól). A tanulmány első felében bemutatott - az urban governance-szel foglalkozó - szakirodalmak, illetve az urban governance definíciói sem kezelik kiemelt módon a városok jogi-közigazgatási környezetét, amely szempontra viszont jelen tanulmány tapasztalatai felhívják a figyelmet. A négy város eltérő közigazgatási rendszerbe eltérő jogi eszközrendszerrel ágyazódik be, amely eltérő módon oszlik el a város belső szereplöi között, s ezáltal a városi kormányzás feltételeit is nagyban befolyásolhatja. A városi közigazgatás stabilitása is fontos szempont lehet, föként a politikai változások által gyakran érintett Közép-Európában. Éppen ezért a városok külső és belső jogi környezetének és azok időbeli módosulásainak tanulmányozása elmaradhatatlan részét kell, hogy képezze a városi kormányzási kutatásoknak.

\section{Jegyzetek}

1 A városrégió tipizálásának azonban még nagyon sokféle módozata lehet (Tosics 2008).

2 A cseh törvényhozás 565/1990. törvénye igen széles körben teszi lehetővé adók kivetését a fövárosi önkormányzatnak (Horak 2007). 


\section{Irodalom}

1990. évi LXV. törvény a helyi önkormányzatokról

1994. évi LXIII. törvény a helyi önkormányzatokról szóló 1990. évi LXV. törvény módosításáról

2011. évi Magyarország Alaptörvénye

2011. évi CLXXXIX. törvény Magyarország helyi önkormányzatairól

53/2014. (XII. 12.) Föv. Kgy. rendelet - a Fővárosi Önkormányzat Szervezeti és Müködési Szabályzatáról

Amtsblatt Wien (2007): Geschäftsordnung für den Magistrat der Stadt Wien (GOM). ABl. 28/2007.

Brenner, N. (2004): New state spaces, Urban governance and the rescaling of statehood. Oxford University Press, Oxford http://doi.org/cg6fjt

Council of Europe (2002): Management of European capital cities. Council of Europe Publishing, Strasbourg

Dövényi Z., Knabe, U. (2007): Budapest és Lipcse közigazgatási beosztása, mint a rendszerváltozás utáni városfejlődés fontos tényezője. In: Kondor A., Egedy T. (szerk.): Városfejlődés és városrehabilitáció: budapesti és lipcsei tapasztalatok. Magyar Földrajzi Társaság, Budapest, 13-19.

Eckardt, F., Elander, I. (2009): Urban governance in Europe. Berliner Wissenschafts-Verlag, Berlin

Harvey, D. (1989): From managerialism to entrepreneurialism: The transformation in urban governance in late capitalism. Geografiska Annaler. Series B, Human Geography, 1., 3-17. http://doi.org/cphc

Hegedüs J. (2008): A nagyvárosi kormányzatok és az önkormányzati rendszer. Tér és Társadalom, 1., 59-75.

Hilbert B. (2017): Budapest, Bécs, Prága és Varsó közötti városdiplomáciai kapcsolatok. Településföldrajzi Tanulmányok, 2., 41-59.

Horak, M. (2007): Governing the post-communist city. Institutions and democratic development in Prague. University of Toronto Press, Toronto, Buffalo, London http://doi.org/cphd

Jelinek Cs., Pósfai Zs. (2013): Bevezetés: A városi önkormányzattól a városi kormányzásig. In: Jelinek Cs., Bodnár J., Czirfusz, M., Gyimesi Z. (szerk.): Kritikai városkutatás. L'Harmattan Kiadó, Budapest, 145-154.

Landesgesetzblatt (LGBl.) Wien (é. n.): Verfassung der Bundeshauptstadt Wien (Wiener Stadtverfassung - WStV). LGBl. 1968/28. és módosításai: LGBl. 22/1992., LGBl. 91/2001., LGBl. 19/2009., LGBl 1/2013., LGBl 46/2013.

Moreno, A.-M. (2012): Local government in the member states of the European Union. A comparative legal perspective. Instituto Nacional de Administratión Pública, Madrid

Nr. XXII/743/2008. Rady Miasta Stołecznego Warszawy z dnia 10 stycznia 2008 rok

Pálné Kovács I. (2008a): Az új várospolitika kormányzási filozófiája. Tér és Társadalom, 1., 45-57.

Pálné Kovács I. (2008b): Helyi kormányzás Magyarországon. Dialóg Campus Kiadó, Budapest, Pécs

Pálné Kovács I. (2010): Városi terek kormányzása és a városi rezsimek. Egy induló kutatás margójára. Tér és Társadalom, 4., 3-27.

Perger É. (2004): A fóváros és „környéke” régióként való értelmezése, a „központi” régió problémája. In: Horváth M. T. (szerk.): A regionális politika közigazgatási feltételei. Magyar Közigazgatási Intézet, Budapest, 213-254.

Předpis č. 418/1990. Zákon České národní rady o hlavním městě Praze

Rhodes, R. A. W. (1997): Reinventing Whitehall 1979-1995. In: Kickert, W. (ed.): Public management and administrative reform in Western Europe. Edwar Elgar, Cheltenham, 43-61.

Slack, E., Côté, A. (2014): Comparative urban governance. Foresight, Government Office for Science, London

Somlyódyné Pfeil E. (2008): A városi térségek a közigazgatási struktúra és a „governance” keresztmetszetében. Tér és Társadalom, 1., 27-43.

Stadt Wien (2011): Organisation der Wiener Stadtverwaltung. Wograndl, Mattersburg

Stone, C. (1989): Regime politics. University Press of Kansas, Lawrence

Sulyok T. (2015): Budapest és Bécs önkormányzati választójogi rendszereinek összehasonlítása. Alkotmánybírósági Szemle, 1., 87-91.

Tosics I. (2008): Nagyvárosi kormányzás: A város és környéke együttműködése. Külföldi példák és a hazai relevancia. Tér és Társadalom, 1., 3-25.

Tóth L., Sági J. (2009): Városok és önkormányzatok: központi kormányzat és spontán szerveződések itthon, a nagyvilágban. EU Working Papers, 2., 118-127. 